\title{
KEEFEKTIFAN MODEL TGT BERBANTU PERMAINAN TEBAK GERAK UNTUK MENINGKATKAN KREATIVITAS PADA PEMBELAJARAN TEMATIK
}

\author{
Tri Wahyuningsih ${ }^{1}$, Ratna Wahyu Pusari ${ }^{2}$, Singgih Adhi Prasetyo ${ }^{3}$ \\ Fakultas Ilmu Pendidikan, Universitas PGRI Semarang \\ email: Ayutriwahyuningsih10@gmail.com
}

\begin{abstract}
In thematic learning the learning independence of students is still lacking and has not optimized the ability to think creatively to improve their creativity due to a lack of confidence so that they have not achieved maximum learning outcomes. Efforts to improve using the Team Games Tournament model are aided guessing motion in games. The method used in this study is quantitative research. This research is a pre-experimental design with one group pretest-posttest design. The research subjects were fifth grade students of Wonosoco Kudus Elementary School with a total of 20 students. The results of the study showed that learning using the Team Games Tournament model is aided the guessing motion in game to improve the creativity of class $V$ children viewed from the pretest average of 60.55 and the posttest average of 83.35. This is evidenced by the $t$ test of $t_{\text {count }}$ $(15,630)>t_{\text {table }}(1,684)$ then $H_{0}$ is rejected and Ha is accepted. So the conclusion is effective using the Team Games Tournament (TGT) model with guessing motion in games improve children's creativity in thematic learning.
\end{abstract}

Keywords: TGT Model, Children's creativity, thematic learning

\begin{abstract}
Abstrak
Dalam pembelajaran tematik kemandirian belajar peserta didik masih kurang dan belum mengoptimalkan kemampuan berfikir kreatif untuk meningkatkan kreativitasnya karena kurangnya rasa percaya diri sehingga belum mencapai hasil pembelajaran yang maksimal. Upaya meningkatkan menggunakan model Team Games Tournament berbantu permainan tebak gerak. Metode yang digunakan dalam penelitian ini adalah penelitian kuantitatif. Penelitian ini merupakan penelitian pre-Experimental design dengan jenis one group pretest-posttest design. Subjek penelitian adalah siswa kelas V SD Negeri Wonosoco Kudus dengan jumlah 20 siswa. Hasil penelitian menunjukkan bahwa pembelajaran menggunakan model Team Games Tournament berbantu permainan Tebak Gerak untuk meningkatkan kreativitas anak kelas V di lihat dari rata-rata pretest 60,55 dan rata-rata posttest 83,35 . Hal tersebut dibuktikan dengan uji $t$ sebesar $t_{\text {hitung }}(15,630)>t_{\text {tabel }}(1,684)$ maka $\mathrm{H} 0$ Ditolak dan Ha Diterima. Jadi kesimpulannya efektif menggunakan model Team Games Tournament (TGT) berbantu permainan Tebak gerak Untuk Meningkatkan Kreativitas Anak Pada Pembelajaran Tematik.
\end{abstract}

Kata Kunci : Model TGT, Kreativitas anak, pembelajaran tematik 


\section{PENDAHULUAN}

pembelajaran tematik tidak lagi berpusat pada guru, tetapi pembelajaran diharapkan lebih banyak untuk memusatkan pada aktivitas siswa (Student Center) guru hanya sebagai fasilitator dalam pembelajaran dapat merancang pembelajaran agar siswa mampu menyelesaikan permasalahanpermasalahan yang kontekstual dan nyata yang memiliki kecakapan dan pengetahuan untuk hidup secara layak (hard skills) dari siswa yang meliputi aspek kompetensi sikap, pengetahuan, dan keterampilan.berdasarkan hasil observasi di SDN Wonosoco belum dapat mengoptimalkan dalam berfikir untuk memberikan ide kreatif, dan inovasi pada peserta didik.

Perlunya inovasi dalam pembelajaran tematik diharapkan siswa dapat tertarik dengan pembelajaran dapat meningkatkan berfikir kreatif siswa. Munandar (2009:12) Kreativitas merupakan bakat yang secara potensial dimiliki oleh setiap orang, yang dapat ditemukan (diidentifikasi) dan dipupuk melalui pendidikan yang tepat, salah satu masalah yang kritis ialah bagaimana dapat menemukenali potensi kreatif siswa dan bagaimana dapat mengembangkannya melalui pengalaman pendidikan. Peserta didik umumnya kurang aktif berpartisipasi dalam proses pembelajaran, kemandirian belajar peserta didik masih kurang dan belum mengoptimalkan kemampuan berfikir kreatif untuk meningkatkan kreativitasnya untuk menyelesaikan suatu permasalahan karena kurangnya rasa percaya diri sehingga belum mencapai hasil pembelajaran yang maksimal.

Pembelajaran dapat berhasil suatu pembelajaran tidak hanya ditentukan hasil belajar yang maksimal, namun menuntut siswa untuk berfikir kritis dan kreatif, namun dalam SD Negeri Wonosoco siswa masih sulit dalam memahami materi, sehingga masih kurangnya siswa yang dapat meningkatkan kreativitasnya dengan baik karena kurangnya rasa percaya diri siswa, selain itu guru masih belum menambahkan model pembelajaran maka yang terjadi dalam pembelajaran masih gaduh, belum dapat mengoptimalkan dalam berfikir 
untuk memberikan ide kreatif, dan inovasi pada peserta didik.

Menurut Fathurrohman (2017:29) mengatakan bahwa model pembelajaran adalah kerangka konseptual yang digunakan sebagai pedoman dalam melakukan kegiatan pembelajaran. Pada penelitian ini, peneliti menggunakan model TGT (Team Games Tournament) yang dapat lebih mudah menyampaikan materi pelajaran. Menurut Fathurrohman (2017:55) menyatakan "TGT adalah salah satu model pembelajaran kooperatif yang menempatkan siswa dalam kelompok-kelompok belajar yang beranggotakan 5 sampai 6 orang siswa yang memiliki kemampuan, jenis kelamin, dan suku kata atau ras yang berbeda".

Model TGT dipadukan dengan permainan Tebak Gerak, pada model TGT yang digunakan dalam pembelajaran tematik supaya dalam pembelajaran di SD Negeri Wonosoco dapat menarik siswa agar dalam pembelajaran siswa dapat aktif mengikuti pelajaran dan membuat pembelajaran menjadi lebih menyenangkan karena pada model
TGT melibatkan peran siswa sebagai tutor sebaya, aktivitas belajar dengan games yang dikaitkan dengan permainan tebak gerak yang akan dapat kerja sama, keterlibatan belajar dan meningkatkan daya berfikir anak menjadi lebih kreatif sehingga siswa lebih mudah untuk menyelesaikan permasalahan yang ada.

\section{METODE PENELITIAN}

Penelitian ini menggunakan penelitian kuantitatif. Sugiyono (2016:14) mengemukakan bahwa metode penelitian kuantitatif dapat diartikan ssebagai metode penelitian yang berdasarkan pada filsafat positivisme, digunakan untuk meneliti pada populasi atau sampel tertentu, teknik pengampilan sampel pada umumnya dilakukan secara random, pengumpulan data menggunakan instrument penelitian, analisis data bersifat kuantitatif atau statistik dengan tujuan untuk meguji hipotesis yang telah ditetapkan.

Metode penelitian yang digunakan dalam penelitian ini adalah metode eksperimen. Menurut Sugiyono (2016 : 107) menyatakan bahwa dalam penelitian eksperimen 
ada perlakuan (treatment). Diartikan sebagai metode penelitian yang digunakan untuk mencari pengaruh perlakuan tertentu terhadap yang lain dalam kondisi yang terkendalikan. Desain yang digunakan penelitian ini adalah metode Pre experimental Design dengan desain penelitian One Group PreTest PostTest. Subjek penelitian ini adalah Seluruh Siswa kelas V SD N Wonosoco dengan jumlah 20 siswa.

Teknik pengumpulan data dalam penelitian ini dilakukan menggunakan tes, observasi, dokumentasi, wawancara, dan instrumen penilaian kreativitas. Teknik analisis data berupa uji normalitas awal, uji normalitas akhir, uji ketuntasan, uji hipotesis.

\section{HASIL DAN PEMBAHASAN}

Hasil Penelitian ini berupa data hasil belajar siswa dalam kemampuan berpikir yang kreatif antara pretest dan posttest yang menunjukkan adanya peningkatan. Data hasil penelitian disajikan dalam tabel sebagai berikut.

Tabel 1. Data Nilai Kemampuan siswa dalam kreativitasnya dalam pembelajaran Siswa Kelas IV SD N Wonosoco

\begin{tabular}{lccl}
\hline Keterangan & Nilai Terendah & Nilai Tertinggi & Rata-Rata \\
\hline Pretest & 40 & 81 & 60,55 \\
\hline Posttest & 56 & 98 & 83,35 \\
\hline
\end{tabular}

Dilihat dari tabel 1 terdapat jumlah nilai Terendah pretest sebesar 40 dan nilai tertinggi sebesar 81 . serta hasil rata-rata keseluruhan nilai pretest sebesar 60,55. Sedangkan dapat dilihat dari hasil posttest siswa yang menunjukkan nilai terendah sebesar 56 dengan nilai maksimal sebesar 98. Dan peningkatan rata-rata sebesar 87,1 Secara umum nilai siswa meningkat, sehingga terdapat peningkatan rata-rata.

Hasil pre test dan post test selanjutnya dibandingkan menggunakan uji $\mathrm{t}$ yang bertujuan untuk mengetahui ada tidaknya peningkatan hasil kemampuan dalam berfikir yang kreatif sehingga dapat meningkatkan kreativitas siswa dengan munculnya rasa percaya diri 
yang dapat diketahui saat menggunakan model Team Games pembelajaran. Sebelum dan sesudah Tournament (TGT).

diberi perlakuan pembelajaran

Tabel 2. Hasil Uji T

\begin{tabular}{cccccc}
\hline \multirow{2}{*}{ Sampel } & \multicolumn{2}{c}{ Rata-Rata } & N & Thitung & T tabel \\
\cline { 2 - 3 } & Pretest & Posttest & & & \\
\hline Kelas V SD N Wonosoco & 60,55 & 83,35 & 20 & 15,630 & 1,684 \\
\hline
\end{tabular}

Berdasarkan hasil perhitungan data dan tabel 2 dapat diperoleh ratarata pretest 60,55 dan rata-rata posttest 83,35 dengan $\mathrm{db}=\mathrm{N}-1=$ $20-1=19$ diperoleh thitung 15,630 menggunakan taraf signifikan 5\% diperoleh $t_{\text {tabel }}$ 1,684. Sehingga, $t_{\text {hitung }}(15,630)>t_{\text {tabel }}(1,684)$ maka $\mathrm{H}_{\mathrm{a}}$ diterima sehingga pembelajaran menggunakan model Team Games Tournament berbantu permainan Tebak gerak berpengaruh terhadap perbedaan hasil pretest dan posttest untuk meningkatkan kreativitas siswa dalam pembelajaran tematik kelas $\mathrm{V}$ SD N Wonosoco.

Hal tersebut sesuai dengan penelitian yang dilakukan oleh Inayatuz Zakiati (2018) yang berjudul "Keefektifan Model Team Games Tournament berbasis Discovery Learning berbantu media engklek tematik terhadap karakter rasa percaya diri siswa kelas IV" Hasil analisis peningkatan hasil belajar siswa yang dihitung menggunakan uji-t dan uji ketuntasan belajar. Untuk perhitungan uji-t diperoleh $\mathrm{t}_{\text {hitung }}$ sebesar 1,828 dan $\mathrm{t}_{\text {tabel }} 1,725$. penggunaan model Team Games Tournament berbasis Discovery Learning berbantu media pembelajaran Engklek Tematik dapat terbukti efektif digunakan pada penanaman nilai karakter percaya diri siswa kelas IV SDN Desa Pidodokulon.

Pencapaian Kreativitas siswa dalam mengetahui siswa berfikir dengan kreatif sehingga meningkatkan kreativitas siswa dalam memecahkan masalah serta mempunyai rasa percaya diri dapat menggunakan indikator untuk mengukur kreativitas siswa, untuk dapat dikatakan mencapai dalam kreativitas yang baik Jika diperoleh 
Jurnal Sinektik

Volume 3 Nomor 1, Edisi Juni 2020

Prodi PGSD Universitas Slamet Riyadi

ISSN 2620-6560 (print) ISSN 2620-746X (online)

persentase $>50 \%$. Adapun hasil dari tabel di bawah ini :

pencapaian kreativitas dapat dilihat

Tabel 3. Pencapaian penilaian Kreativitas siswa

\begin{tabular}{ccccc}
\hline & \multicolumn{4}{c}{ Indikator } \\
\cline { 2 - 5 } Keterangan & $\begin{array}{c}\text { Berfikir Lancar } \\
\text { (fluency of } \\
\text { Thinking) }\end{array}$ & $\begin{array}{c}\text { Berfikir } \\
\text { Luwes } \\
\text { (Flexibility } \\
\text { of Thinking). }\end{array}$ & $\begin{array}{c}\text { Keaslian } \\
\text { (Orisinalitas) }\end{array}$ & $\begin{array}{c}\text { Kerincian } \\
\text { (Elaboratio) }\end{array}$ \\
\hline Presentase & $80 \%$ & $71 \%$ & $83 \%$ & $78 \%$ \\
\hline Kriteria & Baik & Baik & Sangat Baik & Baik \\
\hline
\end{tabular}

Berdasarkan Tabel 3 untuk mengukur pencapaian kreativitas anak pada masing-masing indikator sudah mencapai kriteria baik pada indikator Berfikir Lancar memperoleh presentase $80 \%$, Berfikir luwes memperoleh presentase $71 \%$ dengan kriteria baik, Keaslian memperoleh presentase $83 \%$ dengan kriteria Sangat baik, sedangkan Kerincian memperoleh presentase $78 \%$ dengan kriteria Baik. Dapat disimpulkan bahwa pada masing-masing indikator dalam mengukur kreativitas anak sudah dapat mencapai kriteria baik.

Hal tersebut sesuai dengan penelitian yang dilakukan oleh Maarif (2014) yang menunjukkan peningkatan kreativitas siswa menunjukkan > $60 \%$ dengan nilai rata-rata kreativitas kelas eksperimen sebesar 83,45 dan rata-rata nilai kreativitas kelas kontrol sebesar 41,97 dengan model pembelajaran Role Playing terhadap kreativitas siswa kelas IV SD Negeri Bandungan 01 Kabupaten Semarang maka terbukti efektif digunakan. Penelitian ini sejalan dengan hasil penelitian Mushafanah, Qoriati dan Novita Rahmanika Yanti (2014) yang menyatakan bahwa ada perbedaan hasil belajar antara siswa yang menggunakan model Team Games Tournament (TGT) dengan yang menggunakan model konvesional.

Pada penelitian ini peningkatan kreativitas siswa dalam pembelajaran siswa tersebut dipengaruhi oleh adanya inovasi dalam pembelajaran dengan menggunakan model Team Games Tournament berbantu 
permainan Tebak gerak siswa antusias dalam pembelajaran dan lebih aktif untuk mengetahui lebih dalam tentang pembelajaran di kelas dan dalam menggali kreativitasnya diketahui pada saat diskusi kelompok siswa dapat menyelesaikan permasalahan dalam pembelajaran tanpa bergantung dengan guru dan dengan percaya diri menyampaikan hasilnya di depan kelas.

\section{SIMPULAN}

Berdasarkan hasil penelitian dan pembahasan dapat ditarik kesimpulan adanya pengaruh ada pengaruh model pembelajaran Team Games Tournament (TGT) dalam meningkatkan kreativitas siswa siswa kelas V SD N Wonosoco. Hal ini dilihat dari hasil analisis uji-t yang menunjukkan bahwa thitung sebesar 15,630 dan $t_{\text {tabel }}$ dengan taraf signifikan $5 \%$ sebesar 1,648 , sehingga $t_{\text {hitung }}>t_{\text {tabel }}$ yang artinya $\mathrm{H}_{0}$ ditolak dan $\mathrm{H}_{\mathrm{a}}$ diterima. Perhitungan uji hipotesis dengan menggunakan uji-t Rata-rata dalam kreativitas siswa pada saat pretest sebesar 60,55 sedangkan rata-rata dalam kreativitas siswa pada saat posttest sebesar 83,35 .

Sehingga dapat disimpulkan bahwa rata-rata posttest lebih tinggi daripada rata-rata pretest. Hal ini menunjukkan bahwa penggunaan model Team Games Tournament (TGT) dapat mempengaruhi dalam kreativitas anak. Berdasarkan kesimpulan di atas, penulis mengemukakan beberapa saran yaitu: Diharapkan guru dapat menggunakan model pembelajaran TGT dengan belajar sambil bermain ini mampu memberikan kesempatan yang sama kepada seluruh siswa untuk menyampaikan pengalaman sesuai dengan materi dalam kehidupannya dan menyampaikan pendapat dari hasil diskusi dengan temannya dengan berfikir yang lancar dalam meningkatkan kreativitasnya dalam menyelesaikan masalah. Dikarenakan setiap siswa memperoleh kesempatan yang sama tanpa adanya perbedaan sehingga dapat mengetahui kemampuan serta membantu setiap siswa yang tidak mendapat kesempatan dan keberanian dalam menyampaikan pendapat. 
Volume 3 Nomor 1, Edisi Juni 2020

Prodi PGSD Universitas Slamet Riyadi

ISSN 2620-6560 (print) ISSN 2620-746X (online)

\section{DAFTAR PUSTAKA}

Fathurrohman, Muhammad. 2017. Model-model pembelajaran inovatif. Jogjakarta: Ar-Ruzz Media.

Maarif, Muhammad Anas .2015. Pengaruh Model Pembelajaran Role Playing terhadap Kreativitas dan Hasil Belajar Tematik Integratif Siswa kelas IV SD Negeri Bandungan 01 Kabupaten Semarang. Skripsi Universitas PGRI Semarang: Tidak Diterbitkan.

Munandar,Utami.2009.

Pengembangan Kreativitas Anak Berbakat. Jakarta: Rineka Cipta.

Mushafanah, Qoriati dan Novita Rahmanika Yanti. 2014. Model Teams Games Tournament (TGT) Terhadap Hasil Belajar Siswa Tema Cita-Citaku Kelas IV Sd N 6 Suwawal. Vol.4 (1). Semarang: Universitas PGRI Semarang.

Sugiyono. 2016. Metode Penelitian Pendidikan Pendekatan Kuantitatif, Kualitatif, dan $R \& D$. Bandung: Alfabeta.

Zakiati, Inayatuz .2018. Keefektifan Model Team Games Tournament Berbasis Discovery Learning Berbantu Media Engklek Tematik Terhadap Karakter Percaya Diri Siswa Kelas Iv. Skripsi Universitas PGRI Semarang: Tidak Diterbitkan. 